\title{
CD52 Gene
}

National Cancer Institute

\section{Source}

National Cancer Institute. CD52 Gene. NCI Thesaurus. Code C38907.

This gene is postulated to play a role in the regulation of carbohydrate trafficking;

however this role has not been substantiated. 